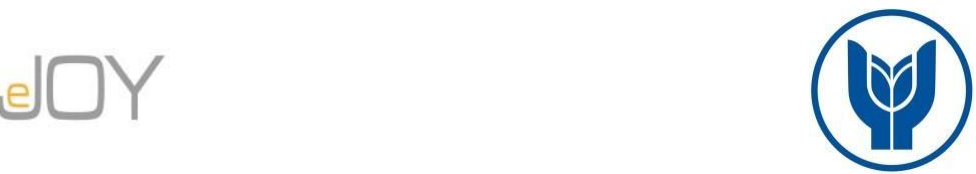

Karacaoğlu, S., Sert, A., N. / Journal of Yasar University, 2019, 14/55, 329-338

\title{
An Evaluation for Participation Motivations of Professional and Non-Professional Visitors: The Case of Travel Turkey İzmir Fair
}

\author{
Profesyonel ve Profesyonel Olmayan Fuar Ziyaretçilerinin Katılım \\ Motivasyonlarına Yönelik Bir Değerlendirme: Travel Turkey İzmir Fuarı \\ Örneği
}

\author{
Sıla KARACAOĞLU, Bilecik Şeyh Edabali University, Turkey, sila.karacaoglu@ bilecik.edu.tr \\ Ayşe Nevin SERT, Selçuk University, Turkey, nevinsert@selcuk.edu.tr
}

\begin{abstract}
One of the major factors that enable the maximization of the benefits of fairs the importance of which is increasing day by day is the determination of the motivations and satisfaction perceptions of the participants. In this context, the study has two main objectives. The first objective is to determine the differences between (1) visitors working in different sectors of the tourism industry as professionals who have come to the Travel Turkey Izmir Fair (2018) and (2) the motivations of visitors who have the potential to participate in tourism activities. The second aim is to examine the relationship between these two different visitor types' satisfaction perception, intention to recommend and intention to revisit. As a result of the survey conducted with 317 visitors participating in the Travel Turkey Fair (2018), it was determined that the main reasons for the participation of all the visitors in the fair were the elements of purchasing, socialization and tourism theme. When the results are examined separately in terms of professional and non-professional, it is noteworthy that the motivations differ. It has been determined that professional visitors participate the fair for seminars, purchasing, ongoing information search purposes while non-professional visitors participated for tourism theme. socialization and escape motivations. The overall satisfaction of the Travel Turkey Izmir Fair (2018) was very high when the relationship between overall satisfaction, intention to revisit and intention to recommend were examined, likewise it was also concluded that the intention to revisit and intention to recommend was also high. On the other hand, there was a moderate positive relationship between the overall satisfaction, intention to revisit and intention to recommend. Furthermore, a strong and positive relationship was determined between the intention to revisit and intention to recommend. The study concludes with suggestions for trade fair organizers to increase the number of visitors to fairs in future years.
\end{abstract}

Keywords: Fair, Visitor, Motivation, Behavioral Intention.

Öz: Önemi gün geçtikçe artan fuarlardan elde edilecek faydaların en üst düzeye çıkarllmasını sağlayan önemli unsurların biri fuara katılanların motivasyonlarının ve memnuniyet algllarının tespit edilmesidir. Bu kapsamda araştırmanın iki temel amacı bulunmaktadır. Birinci amaç; Travel Turkey İzmir Fuarl'na (2018) gelen (1) profesyonel olarak turizm endüstrisinin farklı sektörlerinde çalışan ziyaretçiler ile (2) turizm etkinliklerine katılma potansiyeli olan ziyaretçilerin motivasyonları arasındaki farkların tespit edilmesidir. İkinci amaç ise söz konusu iki farklı ziyaretçi tipinin fuara ilişkin memnuniyet algısı, tavsiye etme niyeti ve tekrar ziyaret niyeti arasındaki ilişkilerin incelenmesidir. Travel Turkey Fuarı'nda (2018) katılan 317 ziyaretçi ile yapılan anket sonucunda fuarı ziyaret edenlerin tamamının ana katılım nedenleri incelendiğinde satın alma, sosyalleşme ve fuar özellikleri unsurlarının ön plana çıktığı saptanmıştır. Sonuçlar, ticari katılımcılar ve tüketiciler nezdinde ayrı ayrı incelendiğinde ise motivasyonların farklılaştığ dikkat çekmektedir. Profesyonel turizm ve seyahat işletmecilerinin eğitim alma, satın alma, devam eden bilgi arayışı ve eğitim alma; tüketicilerin ise fuar özellikleri, sosyalleşme ve kaçıș motivasyonları ile fuara katıldıkları tespit edilmiștir. Tüm ziyaretçilerin Travel Turkey İzmir Fuarı'na (2018) yönelik genel memnuniyet, tekrar ziyaret ve tavsiye etme niyetleri arasındaki ilişkileri incelendiğinde genel memnuniyetin oldukça yüksek olduğu; benzer biçimde ziyaretçilerin tekrar ziyaret etme ve tavsiye etme niyetlerinin de yüksek olduğu sonucuna ulaşılmıştır. Öte yandan, fuardan genel memnuniyet ile tekrar ziyaret ve tavsiye etme arasında orta düzeyde pozitif bir ilişki saptanmıştır. Ayrlca, tekrar ziyaret etme niyeti ile tavsiye etme arasında da kuvvetli ve pozitif bir ilişki belirlenmiştir. Araştırma, gelecek yıllardaki fuarlara ziyaretçi katılım sayılarını artırmaya yönelik fuar organizatörlerine yönelik öneriler ile son bulmaktadır.

Anahtar sözcükler: Fuar, Ziyaretçi, Motivasyon, Davranışsal Niyet.

\section{Introduction}

Fairs can be addressed in a wide range of events ranging from small local events to large-scale international events that attract tens of thousands of visitors (Lee and Lee 2014). The fair industry is growing every year, and the figures manifest the extent of the relevant growth. According to the report published by the Global Relationship of Exhibition Industry (UFI), 31,000 exhibitions were organized worldwide in 2014, including a total of approximately 260 million people who visited 124 million stands that had been rented by 4,4 million participants who qualified as operations (The Global Relationship of Exhibition Industry-UFI 2014). According to another study carried out by UFI in 2016, 2596 fairs were organized in 25 countries in Europe including Turkey. About 725 thousand participants and 71.6 million visitors came to these fairs. An examination of fair categories according to industries reveals that 45 exhibition organizations with a travel theme were organized in Europe in 2016 (UFI 2016). On the other hand 475 fairs in total were organized in Turkey in 2017,348 of which were national and 127 were international. The number of visitors to fairs is approximately 22 million local and foreign visitors. Approximately 200 thousand local and foreign visitors participated in these fairs. When the 
fairs are separated according to services and product groups, the number of tourism-themed fairs is revealed as 9 (Türkiye Odalar ve Borsalar Birliği-TOBB 2019).

Trade fairs are gaining importance in marketing and promotion of enterprises and enterprises participating in fairs aim to achieve an effective combination of marketing and communication. Through fairs, businesses can create awareness for their new customers, consolidate existing customer relationships, promote products, establish relationships with vendors and potential customers, sell goods and services, and perform all these activities at a single point (Lee and Kang 2014). On the other hand, fairs can provide participants or visitors with unique opportunities to explore trends in the market and may be an important source of information for their possible future purchasing (Tanner, Chonko and Ponzurick 2001). In terms of tourism, fairs are service sectors that generate added value by including accommodation, food and beverage, transportation, entertainment and other service sectors (Lee and Kang, 2014). In the United States, one-fifth of marketing activities expenses is spent on fairs (Lee, Yeung, Dewald 2010). Rittichainuwat and Mair (2012) stated that one of the three marketing activities that the tourism enterprises allocate the most resources to is participation in fairs.

In today's competitive environment, the common goal of trade fair organizers and participants is to maintain the number of fair visitors and add new ones. A better understanding of the reasons why visitors participate in trade fairs can help fairs establish a more effective customer relationship management tool in today's business environment (Lee et al. 2010). Visitors are the main customers of both the fair organizers and the professional participants (Jung 2005). Therefore, it is necessary for the success fairs that the factors affecting the participation decisions of visitors are determined. When studies regarding participants are examined, it is noted that the studies are made with professionals who come to fairs for commercial purposes and open stands (Kozak 2005; Lee, Lee and Joo 2015; Reinhold 2016), visitors who have noncommercial purpose and have the potential of purchasing a tourism product (Kozak and Kayar 2009; Dalgic, Birdir and Birdir 2016) and / or both groups (Hansen 1996; Menon and Edward 2014). However, when literature is examined, no comparisons regarding the profiles of visitors participating in fairs have been encountered. Therefore, a comparative study on (1) visitors who work in different sectors of the tourism industry professionally, and (2) exploration of the motivation of visitors who have the potential to participate in tourism activities and the overall satisfaction, intention to revisit and intention to recommend in terms of the two types of visitors is expected to contribute to the relevant literature.

Professional visitors are those who work in different sectors of the tourism industry such as hotels, restaurants, travel agencies, transportation companies, organization and entertainment services who earn money from these jobs. Nonprofessional visitors with the potential to participate in tourism activities are those who are not involved professionally but are likely to buy tourist products as a consumer. In short, (1) professional visitors working in different sectors of the tourism industry are professional visitors while (2) visitors with potential to participate in tourism activities and not work in tourism industry are non-professional visitors in the study. In light of all this information, the study has two main objectives. Firstly, the aim was to determine and compare the motivations of professional visitors and non-professional visitors attending the 12th Travel Turkey Izmir Fair organized in Izmir during 6-8 December 2018. The second aim was to examine and compare the relationship between the overall satisfaction of the two different visitor types as well as their intent to revisit and intent to recommend.

\section{Conceptual Framework}

Fairs are defined as marketing activities that can attract a large number of companies and visitors at a certain time (Chung, Koo and Kim 2014). Fairs are an important component of trade events of the industry comprised of meetings, incentives, conventions and exhibitions (MICE) industry (Lee et al. 2010) which can be divided into three, namely trade shows, consumer fairs and hybrid fairs (Ivkov, Blesi and Ralji 2015; Wei and Lin 2015). Trade fairs are only open to invited customers, suppliers and the media. On the other hand, consumer fairs are open to the public to provide information and sell products directly to non-professional visitors. Finally, hybrid fairs are a mixture of both fairs and are open to the professionals during the first days of the fair (usually on weekdays) and to the public during the last days of the fair (usually on weekends) (Rittichainuwat and Mair 2012). Although they are divided into different categories, fairs provide significant advantages for three major stakeholders: exhibitors, visitors and fair organizers (Rittichainuwat and Mair 2012). Fairs are an effective marketing sales tool that provide participants with the opportunity to establish brand images, fulfill the needs of potential buyers, differentiate from competitors, gain a competitive advantage, fulfill corporate social responsibility, networking, financial and direct sales (Smith, Hama and Smith 2003; Lee and Kang 2014). On the other hand visitors get the opportunity to collect information on goods and services for future purchases, to search for different goods and services, to compare brands and to enjoy entertainment at fairs, as well as to see the latest innovations before they are marketed (Ivkov et al. 2015).

Furthermore, fairs offer face-to-face and experiential marketing (where customers can use all their senses such as touching, smelling, tasting, talking and listening before buying) (McAllan, Criscione and Rees 2008). In addition, they contribute to the development of economic benefits and image in terms of destinations (McCartney 2008; Kim and Chon 2009). On the other hand, in terms of trade fair organizers, participants and visitors are highly profitable customers (Lee et al. 2010), and it has been concluded that they spend about 50\% more than average tourists (Kim, Chon and Chung 2003). In addition, economically the trade fair industry has a strong multiplier effect for business lines such as hotels, restaurants, retail stores, transport etc. (Kim and Chon 2009). In short, trade fairs are important value-adding service industries that have economic returns for fair organizers and / or destinations, promote exports, generate added value for 
other sectors and increases the image of destinations (Whitfield and Webber 2011). It is also an important distribution channel that enables participants and visitors, buyers and sellers to come together at one point, at the same time (Kozak 2005).

It is safe to say that with a view on the power of fair organizations to influence many sectors with projects commissioned for special stands, fair hostesses, cleaning work, promotions, brochures, catalogs, digital banner works, transportation and accommodation services, food and sightseeing programs, they make a major contribution on a local and regional basis (Demirci and Arslaner 2012). In addition, structuring local businesses with a view on fulfilling the wishes and expectations of participants and visitors and increasing their satisfaction is important in terms of improving the infrastructures and superstructures in the province and region. In this sense, it is accepted that fair organizations have important effects in terms of the revitalization and development of local economies (Demirci and Arslaner 2012).

Motivation is a concept that is used to scientifically explain the behavior of people as well as their desires and needs. It is important to determine the motivations of the professionals and visitors in terms of the success and sustainability of fairs that provide many benefits for all of their stakeholders. However, as the visitor profiles differ according to the fair types, it is difficult to investigate these motivations (Rittichainuwat and Mair 2012). For this reason, motivations have been grouped according to visitor type (Ivkov et al. 2015). Some studies have divided fair visitors into two basic groups according to their motivation, namely "buyers" (purchasers) and "non-buyers" (non-purchasers) (Tanner et al. 2001; Smith et al. 2003; Lee and Kang 2014). Buyers are naturally engaged in the purchase of goods and services, while non-buyers are grouped according to their motivation for ongoing information search, networking and participation in seminars. Tanner et al. (2001) argued that non-buyers could become regular customers one day and suggested that necessary interest and attention should be shown accordingly. Another grouping has been established by separating the "commercial" (those who seek to establish direct contact with other companies participating in the fair and to explore cooperation opportunities), "professionals" (mostly those who participate in seminars, workshops) and the "public" (those who want to spend a day at the fair as part of their leisure, cultural and educational activities) into three groups (Ivkov et al. 2015; Berne and Garcia-Uceda 2008). Determinations regarding the prominent motivations of visitors with different characteristics have been carried out in the conducted studies. Tanner et al. (2001) stated that the motivations of fair visitors have three dimensions: shopping, career development and general information about the industry. In his study about fair participants Kozak (2005) grouped the participants; motivation in three headings, selling related activities, promotion related activities and research related activities. Breiter and Milman (2006) determined that the main motivations for participation in fairs were networking, obtaining information about new products, quality of the exhibitors, destination image and reputation of exhibitors. In another study, Kozak and Kayar (2009) showed that visitors to fairs were motivated to follow entertainment, developments, exhibition facilities, vacationing. Zhang (2010) gathered the motivation of fair visitors under five headings: educational benefits, personal attraction, self-development, convenience, and activities. In their study Lee, et al. (2010) compared those who attended trade fairs and general fairs and collected the relevant motivations under five factors, namely fulfillment of business needs, networking opportunity, information search, reward (incentive) travel, market investigation. In the study by Whitfield and Webber (2011) meeting experts and getting information are manifested as the most important motivations. Rittichainuwat and Mair (2012) determined that the dimensions of motivation are buying products, getting discounts and special promotions, examining products before making a decision, collecting information for future purchases and being interested in exhibition theme. In their study in India, Nayak and Bhalla (2016) collected the motivation of visitors to a handicraft fair under four heading, namely learning, maintaining awareness, purchasing and attraction. Huang (2016) in his study with the Taiwanese enterprises participating in fairs indicated factors affecting the decision-making process, selling activity, information gathering, relationship building, fair image and extension service as motivation factors. Yi, Fu, Jin and Okumus (2018) examined the push and pull motivation of visitors. They reported that the pull motivation plays a more important role. They argued that the organizer's experience, hardware appearance, softer aspects, publicity are important.

It is apparent that the information search is an important motivation for participation in fairs for professionals. Professionals take part in fairs to see where they are with the competition, learn about the goods and services of other businesses, and to establish sales links. The information they obtain at the fairs makes them more competitive and enables them to effectively adapt to changes in the international business environment in terms of cost and time (Smith et al. 2003; Whitfield and Webber 2011; Rittichainuwat and Mair 2012). Another prominent motivation is networking (Breiter and Milman 2006; Whitfield and Webber 2011). Breiter and Milman (2006) stated that visitors were able to communicate and exchange information with participants, current suppliers, buyers and other visitors and thus expand their networks. In addition, mainly professional visitors participate in seminars, workshops and social events to establish and / or maintain networks during fairs (Smith et al. 2003).

An examination of literature indicates, as shown above, that the studies have been carried out in different fairs and countries. However, the general motivation of visitors can be listed as learning about new products, improve themselves, benefit from discounts and establish networks (Godar and O'Connor 2001; Tanner et al. 2001; Simit et al. 2003; Lee et al. 2010).

\section{Materials and Method}


The population of this study consists of visitors who attended the Travel Turkey Izmir Fair on 6-8 December 2018. Sampling was used in this study instead of the whole population due to constraints such as time and cost; the sample group was established with the stratified sampling method to include individuals with different gender, age, education etc. demographic characteristics in the sample. Accordingly, the formula $n=S^{2} Z_{\alpha}{ }^{2} / d^{2}$ recommended for quantitative studies and large populations by Özdamar (2001) was used to calculate the sample size. A pilot study for 30 persons was carried out to determine the parameters in the formula and the standard deviation was taken as $\mathrm{S}=0.9$ while $\mathrm{Z} \alpha=1.96$ was taken as $\alpha=0,05$ significance level and $d=0.1$ was taken as impact width. In this respect, the minimum sample size was calculated as $311 ; 350$ questionnaires were distributed taking missing, defective and unreliable questionnaires into consideration and 317 of them were evaluated.

A 3-part survey technique was used as a data collection tool in the study. The first part consisted of 10 questions regarding the individual characteristics of the respondents as well as fair related issues (gender, occupation, age, level of education, marital status, income status, employment status in tourism, frequency in participation in tourism fairs, frequency in participating in Travel Turkey Izmir Fair and information source). The respondents were divided into two groups as professionals (those working in the tourism sector) and non-professionals (those not working in the tourism sector) according to their employment in a tourism sector. In the second part of the survey, the four dimensions (seminars, purchasing, ongoing information search, tourism theme) from the study of Rittichainuwat and Mair (2012) were adapted to establish the motivation scale regarding the reasons for participating in Travel Turkey Izmir Fair while the remaining two dimensions (socialization and escape) were taken from the work of Kim, Aao, Lee and Pan (2012) to total 20 items. The third part of the questionnaire consists of questions that include the variables for "intention to revisit" "intention to recommend" and "overall satisfaction". The revisit and recommendation scales were taken from Kim, Kim and Kim's (2009) study, overall satisfaction scales adapted from Prayag, Hosany, Muskat ve Del Chiappa (2017). In the questionnaire, the 5-point Likert Scale (1=Strongly Disagree, 2= Disagree, 3=Neither Agree Nor Disagree, 4= Agree, $5=$ Strongly Agree) was used for the reasons for visitors motivations, intention to revisit, intention to recommend. The level of satisfaction is rated in the interval with $1=$ Not at all satisfied , 2= Slightly Satisfied, $3=$ Moderately Satisfied, $4=$ Very Satisfied and 5= Extremely Satisfied.

The internal consistency of the motivation scale for reliability analysis was calculated with Cronbach's Alpha coefficients in the study. Demographic characteristics of the participants were presented with frequency and percentage distributions and descriptive statistics such as arithmetic mean and standard deviation were used for the percentage distribution of each item and dimensions on the motivation scale. On the other hand, in the comparison of the motivation of the fair visitors according to the status of professionalism (whether or not they work in a tourism related business), a ttest (independent samples t-test) was applied for independent samples since parametric test assumptions were carried out. Furthermore, the overall satisfaction of participants, their intention to revisit and recommend relationship was determined with Pearson Correlation Coefficients. SPSS 18.0 for Windows was used for data analysis.

\section{Results and Analysis}

The distribution of the participants according to their demographic characteristics is presented in Table 1. According to this, $69.4 \%$ of the total 317 participants were male, $62.8 \%$ were married, $72.2 \%$ were under $39,50.1 \%$ were maximum high school graduates, $36.3 \%$ were employed, $32.2 \%$ were self employed and $73.2 \%$ had an income level of $5000 \mathrm{TL}$ and less. $18 \%$ of the participants stated that they work in tourism related businesses, $30 \%$ had never participated in a tourism fair and $67.5 \%$ indicated that they had not participated in the Travel Turkey Izmir Fair before. 34.7\% of the participants used social media applications while $24.9 \%$ had business environments and $23 \%$ had friends, family, and so on who had informed them about Travel Turkey Izmir Fair.

Table 1. Distribution of the participants according to their demographic characteristics

\begin{tabular}{|c|c|c|c|}
\hline Variables & Groups & Number (n) & Percentage (\%) \\
\hline \multirow[t]{2}{*}{ Gender } & Female & & \\
\hline & Male & 220 & 69.4 \\
\hline \multirow[t]{2}{*}{ Marital status } & Married & 199 & 62.8 \\
\hline & Single & 118 & 37.2 \\
\hline \multirow[t]{4}{*}{ Age } & Under 29 & 78 & 24.6 \\
\hline & Between 30-39 & 151 & 47.6 \\
\hline & Between 40-49 & 62 & 19.6 \\
\hline & 50 and over & 26 & 8.2 \\
\hline \multirow[t]{4}{*}{ Education } & Elementary school and less & 21 & 6.6 \\
\hline & High school & 138 & 43.5 \\
\hline & Bachelor degree & 135 & 42.6 \\
\hline & Master's degree or higher & 23 & 7.3 \\
\hline \multirow[t]{2}{*}{ Profession } & Employer & 30 & 9.5 \\
\hline & Employed & 115 & 36.3 \\
\hline
\end{tabular}


Karacaoğlu, S., Sert, A., N. / Journal of Yasar University, 2019, 14/55, 329-338

\begin{tabular}{|c|c|c|c|}
\hline & $\begin{array}{l}\text { Self employed } \\
\text { Other (student, } \\
\text { unemployed, etc.) }\end{array}$ & $\begin{array}{r}102 \\
70\end{array}$ & $\begin{array}{l}32.2 \\
22.1\end{array}$ \\
\hline Monthly income (Turkish I & $\begin{array}{l}3.000 \mathrm{TL} \text { and less } \\
3.001-5.000 \\
5.001-7.000 \\
7.001 \text { and over }\end{array}$ & $\begin{array}{l}61 \\
24\end{array}$ & $\begin{array}{r}19.2 \\
7.6\end{array}$ \\
\hline $\begin{array}{l}\text { Tourism related professioni } \\
\text { employment }\end{array}$ & $\begin{array}{l}\text { Yes } \\
\text { No }\end{array}$ & $\begin{array}{r}57 \\
260\end{array}$ & $\begin{array}{l}18.0 \\
82.0\end{array}$ \\
\hline $\begin{array}{l}\text { Previous participation } \\
\text { tourism fair }\end{array}$ & $\begin{array}{l}\text { Never participated } \\
\text { I participated once } \\
\text { I participated twice } \\
\text { I participated } 3 \text { and more times }\end{array}$ & $\begin{array}{r}96 \\
159 \\
46 \\
16\end{array}$ & $\begin{array}{r}30.3 \\
50.2 \\
14.5 \\
5.0\end{array}$ \\
\hline $\begin{array}{l}\text { Participation status in }] \\
\text { Turkey Izmir Fair }\end{array}$ & $\begin{array}{l}\text { Never participated } \\
\text { I participated once } \\
\text { I participated } 3 \text { and more times }\end{array}$ & $\begin{array}{r}214 \\
90 \\
13\end{array}$ & $\begin{array}{r}67.5 \\
28.4 \\
4.1\end{array}$ \\
\hline $\begin{array}{l}\text { News about Travel Turkey } \\
\text { Fair }\end{array}$ & $\begin{array}{l}\text { Social media app. } \\
\text { Business environment } \\
\text { Friends, family etc. } \\
\text { TV / Radio } \\
\text { Other (Newspaper, int. etc.) }\end{array}$ & $\begin{array}{r}110 \\
79 \\
73 \\
42 \\
13\end{array}$ & $\begin{array}{r}34.7 \\
24.9 \\
23.0 \\
13.2 \\
4.1 \\
\end{array}$ \\
\hline Total & & 317 & 100,0 \\
\hline
\end{tabular}

Table 2. presents some descriptive statistics about the motivation and reasons of participants for participating in Travel Turkey Izmir Fair. 


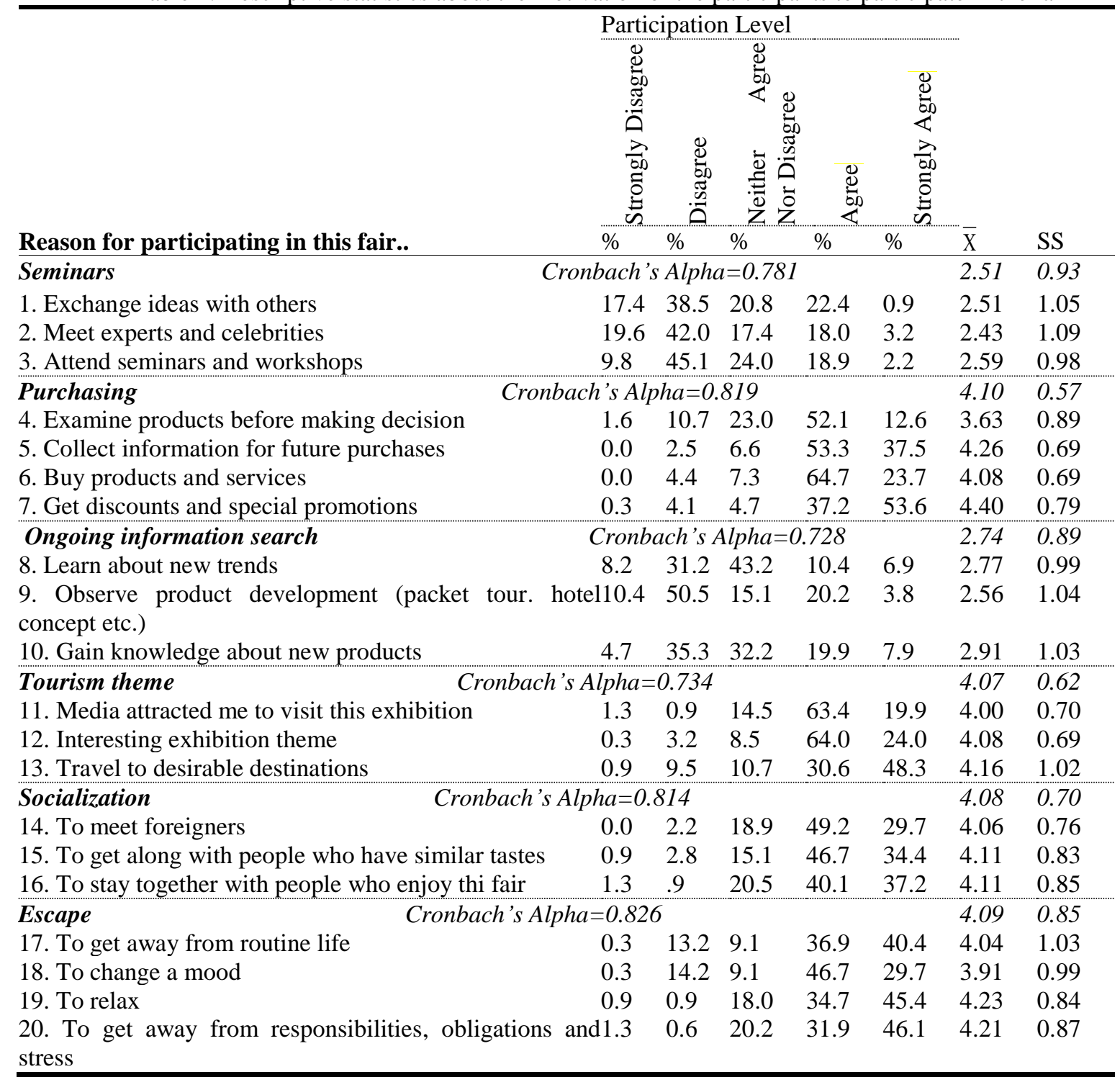

According to Table 2, Cronbach's Alpha values for all sub-dimensions are over 0.70 for internal consistency coefficients in terms of reliability analysis. On the one hand the participants reasons for participation to Travel Turkey Izmir Fair were listed as; "purchase" $(\bar{X}=4.10)$, "escape" $(\bar{X}=4.09)$, "socialization" $(\bar{X}=4.08)$ and "tourism theme" $(\bar{X}=4.07)$. On the other hand it was determined that "seminars" $(\bar{X}=2.51)$ and "ongoing information search" $(\bar{X}=2.74)$ were the least compelling reasons for participation in the fair. In other words it was determined that the participants did not come to Travel Turkey Izmir Fair to get "seminars" and to satisfy their "ongoing information search" or that these were not factors that motivated them to participate. $61.6 \%$ of the participants manifested a negative view with "strongly disagree" and "strongly agree" for the item "meet experts and celebrities in the sector of tourism" regarding the Travel Turkey Izmir Fair indicating that they viewed it to be the least important reason for visiting the fair.

Table 3 presents the t-test results for comparison of the participation motivations of the professional and nonprofessional fair visitors. According to this statistically significant differences were found between professional and nonprofessional fair visitors in terms of all dimensions in the motivation for participating in Travel Turkey Izmir Fair ( $p$ $<0.05)$. When the average values are examined; the motivation of professional fair visitors in terms of the reasons of their participation in the Travel Turkey Izmir Fair in the dimensions of "seminars" ( $\bar{X}=3.03)$ "purchasing" $(\bar{X}=4.26)$ and "ongoing information search" $(\bar{X}=3.30)$ is higher than that of non-professionals; on the other hand it is seen that the motivations of participation of the non-professionals in the dimensions of "tourism theme" $(\bar{X}=4.28)$, "socialization" $(\bar{X}$ $=4.33)$ and "escape" $(\bar{X}=4.39)$ are higher than those for the professionals, reasons of participation in the fair. In addition, the statistics in Table 3 indicate that the most important reason of professional visitors for participating to the Travel Turkey Izmir Fair $(\bar{X}=4.26)$ is purchasing. 
Karacaoğlu, S., Sert, A., N. / Journal of Yasar University, 2019, 14/55, 329-338

Table 3. Comparison of participation motivations of professional and non-professional fair visitors

\begin{tabular}{llcccc}
\hline Dimensions & Groups & $\bar{X}$ & SS & t & p \\
\hline Seminars & Professional & 3.03 & 1.07 & 4.84 & $0.000^{*}$ \\
& Non-professional & 2.39 & 0.86 & & \\
\hline Purchasing & Professional & 4.26 & 0.46 & 2.59 & $0.010^{*}$ \\
& Non-professional & 4.05 & 0.58 & & \\
\hline Ongoing information search & Professional & 3.30 & 0.92 & 5.51 & $0.000^{*}$ \\
& Non-professional & 2.62 & 0.83 & \\
\hline Tourism theme & Professional & 3.15 & 0.66 & -16.81 & $0.000^{*}$ \\
& Non-professional & 4.28 & 0.39 & & \\
\hline Socialization & Professional & 3.00 & 0.51 & & \\
& Non-professional & 4.33 & 0.48 & & $0.000^{*}$ \\
\hline Escape & Professional & 2.71 & 0.56 & -20.53 & $0.000^{*}$ \\
\hline
\end{tabular}

$* p<0.05$

Table 4 shows the correlation coefficients for the relationship between the variables and some general descriptive statistics about the overall satisfaction of the participants regarding the Travel Turkey İzmir Fair and their intention to revisit and intention to recommend. According to the findings in Table 4 the overall satisfaction level for the Travel Turkey İzmir Fair is seen to be quite high (positive) $(\bar{X}=4.47)$ in terms of the maximum value of 5 in the 5-point Likert rating. Likewise it was determined that the intention of visitors to Travel Turkey Izmir Fair to revisit $(\bar{X}=4.31)$ and recommend $(\bar{X}=4.41)$ were also high (positive). On the other hand a moderate positive correlation $(0.40<\mathrm{r}<0.60)$ was determined between the overall satisfaction with the fair $(\mathrm{r}=0.487)$ and recommendation $(\mathrm{r}=0.438)$ while a strong and positive correlation $(0.60<\mathrm{r}<0.80)$ was determined between intention to revisit and intention to recommend $(\mathrm{r}=0.629)$.

Table 4. Some descriptive statistics and the correlation between the participants' overall satisfaction, intention to revisit and intention to recommend

\begin{tabular}{|c|c|c|c|c|c|c|}
\hline & & & & 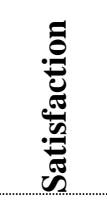 & 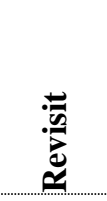 & 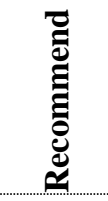 \\
\hline Participants' views & $\mathbf{r}$ & $\overline{\mathrm{X}}$ & SS & $\mathbf{r}$ & $\mathbf{r}$ & $\mathbf{r}$ \\
\hline Overall satisfaction & 31 & 4.47 & 0.57 & - & $0.487^{*}$ & $0.438^{*}$ \\
\hline Intention to revisit & 31 & 4.31 & 0.51 & $0.487^{*}$ & - & $0.629^{*}$ \\
\hline Intention to recommend & 31 & 4.41 & 0.47 & $0.438^{*}$ & $0.629^{*}$ & - \\
\hline
\end{tabular}

\section{Discussion and Conclusion}

The activities that are among the important driving forces of tourism have an important place in terms of the promotion marketing and development plans of destinations that compete on a regional national and international basis (Getz, 2008). Companies that plan and conduct their activities in the fair properly can communicate their messages effectively to their current and potential customers and promote their goods or services (Lee et. al., 2010). In short, fairs which have increased rapidly in importance in today's competitive environment, contribute to fair organizers, exhibitors, visitors and the destination in which they are organized and also provide economic benefits. The success of fairs largely depends on the visitors. Therefore, examining the motivations of the visitors to fairs is very important in terms of fulfilling their needs by the organizers and thus ensuring their satisfaction and revisits (Rittichainuwat and Mair, 2012). The aim of this study is to determine the motivation of professional and non-professional fair visitors and to examine the relationship between the overall satisfaction of the visitors and their intention to revisit and intention to recommend.

In the scope of the study, it was determined that the main reasons for all participants who visited the Travel Turkey Izmir Fair were based on purchasing, socialization and tourism theme. It is noted that the majority of the respondents were those who were not involved in tourism related work, in other words by non-professional. Therefore it is not surprising that the results of the study indicated that the primary motivation of all participants was purchasing, socialization and tourism theme when all the responses are evaluated in general. Both the professional participants' wish to develop their business relationships with each other and make new agreements, as well as the non-professional visitors' 
motivation to buy tourist products. were interpreted as expected results. When the results of the study are examined separately according to professional and non-professional visitors, it is noteworthy that the results differ. The most important reasons for non-professional visitors to attend the fair are tourism theme, socialization and escape factors. Many studies investigating the reasons for participation of people in event tourism have revealed that the most important sociopsychological reasons that attract visitors to the activities are to escape from everyday life (Uysal Gahan and Martin, 1993; Savinovic, Kim and Long, 2012) and socialization (Bowen and Daniels, 2005; Abreu-Novais and Arcodia, 2013; Dos Santos and Montoro Rios, 2016). It can be said that the results of these studies coincide with the current study. It is concluded that two of the motivation factors that most affected non-professional visitors participating in the Travel Turkey fair were internal participations factors such as socialization and escape reasons. On the other hand, when the motivations of professional visitors were examined, it was determined that the elements that come to the fore were learning, purchasing, ongoing information search and training. The outcome is interpreted as a situation that is expected to differ from non-professional visitors.

When the participation of professional visitors in the fair was evaluated, results similar to those observed in many different studies were encountered (Kozak 2005; Lee et al.. 2010; Menon and Edward. 2014). Kozak (2005) investigated the motivation factors of participants in the EMITT fair and found that the motivation of the participants was to increase the morale of employees, gather information for the comparison and marketing activities of competitors' products or services. Lee et al., (2010) found Information search and market investigation to be important motivational factors. Menon and Edward (2014) carried out a study in which they investigated the motivation of employees who participated in a travel and tourism fair and determined that the reasons for visiting the fair as professionals was to gain information about new products, see new features and meet new suppliers. A study by Chung et al., (2014) reported that the common motivation of the visitors is to information gain (research, education, information needs and seminars), escape (excitement) and event attraction (innovation, awareness, shopping). Therefore, it can be said that the results of this study coincide with the determinations in literature.

The intention of visiting again can be defined as a tourist's desire to revisit a previously visited destination. The intention to revisit a destination is considered an extension of satisfaction (Stylos, Vassiliadis, Bellou and Andronikidis, 2016). Therefore, overall satisfaction results in satisfied loyal visitors. In this context, the relationship between the satisfaction of the visitor and the intention to revisit and the intention to recommend is important. In view of the data obtained, it is concluded that the overall satisfaction with the fair is quite high as is the intention of visitors to revisit and recommend. On the other hand, there was a moderate positive relationship between overall satisfaction in the fair and the intention to revisit and intention to recommend. A strong and positive relationship was found between intending to revisit and recommend. These findings can be interpreted as the highly satisfied visitors to the Travel Turkey Fair (2018) will come to this fair again and recommend it to others. This result is similar with the studies in literature (Siu, Wan and Dong, 2012; Dalgic et. al., 2016).

It is believed that the best way to increase the number of visitors to fairs is by having tourism and travel companies participating in the fairs to carry out their commercial advertising and promotional activities in the best way possible (Rittichainuwat and Mair, 2012). In the stud, it was determined that visitors received their initial information about fairs from the social media from news sources about the fair. Therefore, the importance of effective use of the social media by all stakeholders, especially fair organizers and the participant enterprises is manifested.

When the findings of the study are evaluated in general, recommendations can be suggested regarding fair organization considering that the general visit motivations are purchasing, socialization and tourism theme. Organizers can expand their sales development and marketing activities by recognizing that the promotion and attractive features of a fair are very effective in participation in a fair. Considering the current power of the social media, a more effective use of social media applications will be beneficial in increasing participation.

In addition to this, it is thought that diversifying international fairs in terms of activities, giving priority to ethnic music, dances and shows that reflect traditional lifestyle as well as interactive technology-related presentations and demonstrations will affect the number of participants in the coming years. Furthermore, visitors whose expectations have not been fulfilled as a result of business and time constraints during the fair may be expected to display negative behavior patterns in the future. Therefore, monitoring the visitors of the trade fair by organizers and the participating commercial enterprises after the fair can also contribute positively to the participants' overall satisfaction. intention to revisit and recommend. For this purpose, visitors' surveys can be organized, and fairs can be improved in a positive way by asking visitors what features of the fair they are satisfied and not satisfied about. The reasons why professional participants participate in fairs is because fairs establish new environments that enable companies to meet customers, get together and establish connections, test customers' response to new products or services, compile new ideas and influence potential customers and competitors. From this point of view, fair organizers should carry out face to face interviews with commercial companies and take their requests. complaints and opinions.

The study had some limitations as there are in all studies. The most important limitation was the difficulty in the data collection process due to limited activity time. The motivations of professional and non-professional who participated individually were examined within the scope of this study. Furthermore the relationship between overall satisfaction with the fair intention to revisit and intention to recommend was examined. Different aspects of fair management can be researched in different studies. 


\section{REFERENCES}

Abreu-Novais, M., and Arcodia, C. 2013. "Music festival motivators for attendance: Developing an agenda for research". International Journal of Event Management Research, 8(1), 34-48.

Bowen, H. E., and Daniels, M. J. 2005. "Does the music matter? Motivations for attending a music festival". Event Management, 9(3), 155-164.

Breiter, D., and Milman, A., 2006. “Attendees' needs and service priorities in a large convention center: application of the importance-performance theory". Tourism Management, 27(1), 1364-1370.

Berne, C., and Garcia-Uceda, M. E. 2008. "Criteria involved in evaluation of trade shows to visit". Industrial Marketing Management, 37(5), 565-579.

Chung, N., Koo, C., and Kim, J. K. 2014. "Extrinsic and intrinsic motivation for using a booth recommender system service on exhibition attendees' unplanned visit behavior". Computers in Human Behavior, 30(1), 59-68.

Dalgic, A. Sahilli Birdir, S., and Birdir, K. 2017. Turizm temalı fuara katılanların motivasyonları, genel memnuniyetleri ve sadakatleri arasındaki ilişki: Travel Turkey örneği”. 1. Uluslararası Turizmin Geleceği; İnovasyon, Girişimcilik ve Sürdürebilirlik Kongresi, 28-30 September 2017, Mersin, Turkey.

Demirci B. and Arslaner E. 2012. "Fuar organizasyonlarının yerel ekonomiye ve tekrar gelme niyetine etkileri: Bursa örneği”. Sosyal ve Beşeri Bilimler Dergisi, 4(2), 63-73.

Alonso Dos Santos, M., and Montoro Rios, F. J. 2016. "Scale of spectators' motivations at soccer events". Soccer and Society, 17(1), 58-71.

Getz, D. 2008. "Event tourism: Definition, evolution, and research". Tourism Management, 29, 403-428.

Godar, S. H., and O’Connor, P. J. 2001. "Same time next year: buyer trade Show motives". Industrial Marketing Management, 30, 77-86.

Hansen, K. 1996. "The dual motives of participants at international trade shows", International Marketing Review, 13 (2), 39-53.

Huang, H. C. 2016. "How does meetings, incentives, conventions, and exhibitions industry attract exhibitors?". Asia Pacific Journal of Tourism Research, 21(1), 73-93.

Ivkov, M., Bleši'c, I., and Ralji'c, J. P. 2015. "Visitors' motives for attending a hybrid event: A case study of agricultural fair". Economics of Agriculture, 62 (1), 9-28.

Jung, M. 2005. "Determinants of service exhibition quality as perceived by attendees". Journal of Convention and Event Tourism, 7 (3), 85-98.

Kim, S., Chon, K., and Chung, K. 2003. "Convention industry in South Korea: An economic impact analysis". Tourism Management, 24(5), 533-541.

Kim, S. S., and Chon, K. 2009. "An economic impact analysis of the Korean exhibition industry”. International Journal of Tourism Research, 11, 311-318.

Kim, T. T., Kim, W. G., and Kim, H. B. 2009. "The effects of perceived justice on recovery satisfaction, trust, word-ofmouth, and revisit intention in upscale hotels". Tourism management, 30(1), 51-62.

Kim, S., Ao, Y., Lee, H., and Pan, S. 2012. "A study of motivations and the image of Shanghai as perceived by foreign tourists at the Shanghai EXPO". Journal of Convention and Event Tourism, 13 (1), 48-73.

Kozak, N. 2005. "The expectations of exhibitors in tourism, hospitality, and the travel industry: A case study on East Mediterranean Tourism and Travel Exhibition". Journal of Convention and Event Tourism, 7(3-4), 99-116.

Kozak, N., and Kayar, H. C. 2009. "Visitors' objectives for trade show attendance: A case study on the EastMediterranean international tourism and travel exhibition (EMITT)". Event Management, 12(1), 1-17.

Lee, M. J., Yeung, S., and Dewald, B. 2010. "An exploratory study examining the determinants of attendance motivations as perceived by attendees at Hong Kong exhibitions". Journal of Convention and Event Tourism, 11(3),195-208.

Lee, M. J., and Lee, S. 2014. "Subject areas and future research agendas in exhibition research: visitors' and organizers' perspectives". Event Management, 18(3), 377-386.

Lee, M. J., and Kang, Y. S. 2014. 'Subject areas and future research agendas in exhibition research: Exhibitors' perspectives". Event Management, 18(2), 185-194.

Lee, M. J., Lee, S. and Joo, Y. M. 2015. "The effects of exhibition service quality on exhibitor satisfaction and behavioural intentions". Journal of Hospitality Marketing \& Management, 24(7), 683-707.

Menon, S., and Edward, M. 2014. "Exhibitors and visitors' motivations at destination trade shows". International Journal of Services, Economics and Management 4, 6(2), 193-208.

McAllan, F., Criscione, C., and Rees, J. 2008. "Showcase: Consumer exhibitions-advice. Event, March, 41.

McCartney, G. 2008. "The CAT (Casino tourism) and the MICE (Meetings, incentives, conventions, and exhibitions): key development considerations for the convention and exhibition industry in Macao". Journal of Convention and Event Tourism, 9(4), 293-308.

Nayak, J. K., and Bhalla, N. 2016. "Factors motivating visitors for attending handicraft exhibitions: Special reference to Uttarakhand, India". Tourism Management Perspectives, 20(1), 238-245.

Özdamar, K. 2001. "Spss ile biyoistatistik (4.Basım)". Eskişehir: Kaan Kitabevi.

Prayag, G., Hosany, S., Muskat, B., and Del Chiappa, G. 2017. "Understanding the relationships between tourists' emotional experiences, perceived overall image, satisfaction, and intention to recommend". Journal of Travel Research, 56(1), 41-54. 
Reinhold, M. 2016. "Intention to re-exhibit--when does it translate to actual trade fair attendance?: Analyzing the Organizer-Exhibitor Relationship", Monograph (Discussion Paper), 1-23.

Rittichainuwat, B., and Mair, J. 2012. "Visitor attendance motivations at consumer travel exhibitions". Tourism Management, 33(1), 1236-1244.

Savinovic, A., Kim, S., and Long, P. 2012. “Audience members' motivation, satisfaction, and intention to revisit: An ethnic minority cultural festival". Journal of Travel and Tourism Marketing, 29(7), 682-694.

Siu, N. Y. M., Wan, P. Y. K., and Dong, P. 2012. "The impact of the servicescape on the desire to stay in convention and exhibition centers: The case of Macao". International Journal of Hospitality Management, 31(1), $236-246$.

Smith, T., Hama, K., and Smith, P. 2003. "The effect of successful trade show attendance on future show interest: Exploring Japanese attendee perspectives of domestic and offshore international events". Journal of Business and Industrial Marketing, 18(4/5), 403-418.

Stylos, N., Vassiliadis, C. A., Bellou, V., and Andronikidis, A. 2016. "Destination images, holistic images and personal normative beliefs: Predictors of intention to revisit a destination". Tourism Management, 53, 40- 60.

Tanner Jr, J. F., Chonko, L. B., and Ponzurick, T. V. 2001. A learning model of trade show attendance”. Journal of Convention and Exhibition Management 3(3), 3-26.

The Global Relationship of Exhibition Industry-UFI, 2014. "Global exhibition industry statistics", https://www.ufi.org/wp-content/uploads/2016/01/2014_exhibiton_industry_statistics_b.pdf (Access Date: 18.01.2019).

The Global Relationship of Exhibition Industry-UFI, 2016. “Euro fair statistics 2016”, https://www.ufi.org/wpcontent/uploads/2017/09/2017-09_Euro_Fair_Statistics_2016.pdf (Access Date: 18.01.2019).

Türkiye Odalar ve Borsalar Birliği- $\quad$ TOBB. 2019. "Fuar Istatistikleri”. https://tobb.org.tr/FuarlarMudurlugu/Sayfalar/Istatistikler.php (Access Date: 17.01.2019).

Uysal, M., Gahan, L., and Martin, B. 1993.” An examination of event motivations: A case study". Festival Management \& Event Tourism, 1: 5-10.

Wei, Y. P., and Lin, S. (2015). "Factors impacting trade and public visitors' satisfaction in food-related exhibitions in Taiwan". Journal of Quality Assurance in Hospitality and Tourism, 16(3), 283-302.

Whitfield, J., and Webber, D. J. 2011. "Which exhibition attributes create repeat visitation?" International Journal of Hospitality Management, 30(2), 439-447.

Yi, X., Fu, X., Jin, W., and Okumuş, F. 2018. "Constructing a model of exhibition attachment: Motivation, attachment, and loyalty". Tourism Management, 65, 224-236.

Zhang, T. 2010. A study on motivation of meeting and exhibition Attendees in Macao. International Conference on Management and Service Science (MASS), 1-4. 